\title{
The Role of Higher Education in Implementing Pancasila Education MKWU Policy for National Character Development
}

\author{
Tatang Sudrajat \\ Universitas Sangga Buana, Bandung, Indonesia \\ id.tatangsudrajat@gmail.com
}

\section{Article History \\ accepted 23/03/2021}

approved 10/04/2021 published 20/04/2021

\begin{abstract}
The character of the nation is very important for the sustainability of the Indonesian nation's struggle to fill independence by carrying out national development. Value education, including Pancasila Education in tertiary institutions plays a strategic role in preparing nationals with character. Public policy in the field of higher education is a concrete manifestation of the state's function in educating the nation's life. This study aims to describe the role of higher education institutions in implementing the MKWU Pancasila Education policy for the development of national character.

With the normative juridical method and literature study, it is known that the state / government has established a policy of inculcating the values of Pancasila by issuing several public policies in the field of higher education. Universities as policy institutions as well as university leaders and lecturers of MKWU Pancasila Education as policy actors play a major role in building student character as an integral part of the Indonesian nation. Students as policy targets can act as role models for successful implementation. The policy environment contributes to its survival and success. Higher education is faced with several challenges and problems in implementing the policy of planting Pancasila values. There is a policy substance that needs to be refined.
\end{abstract}

Keywords: Pancasila, character, college, policy implementation

\begin{abstract}
Abstrak
Karakter bangsa sangat penting bagi keberlanjutan perjuangan bangsa Indonesia mengisi kemerdekaan dengan melaksanakan pembangunan nasional. Pendidikan nilai, termasuk Pendidikan Pancasila di perguruan tinggi berperan strategis dalam mempersiapkan warga bangsa yang berkarakter. Kebijakan publik di bidang pendidikan tinggi merupakan wujud nyata fungsi negara dalam mencerdaskan kehidupan bangsa. Penelitian ini bertujuan untuk mendeskripsikan peran perguruan tinggi dalam mengimplementasikan kebijakan MKWU Pendidikan Pancasila untuk pembangunan karakter bangsa. Dengan metode yuridis normatif dan studi kepustakaan, diketahui bahwa negara/pemerintah telah menetapkan kebijakan penanaman nilai-nilai Pancasila dengan menerbitkan beberapa kebijakan publik di bidang pendidikan tinggi. Perguruan tinggi sebagai institusi kebijakan serta pimpinan perguruan tinggi dan dosen pengampu MKWU Pendidikan Pancasila sebagai aktor kebijakan berperan besar dalam turut membangun karakter mahasiswa sebagai bagian integral bangsa Indonesia. Mahasiswa sebagai sasaran kebijakan dapat berperan sebagai role model bagi keberhasilan implementasinya. Lingkungan kebijakan turut berkontribusi terhadap keberlangsungan dan keberhasilannya. Perguruan tinggi dihadapkan pada beberapa tantangan dan permasalahan dalam mengimplementasikan kebijakan penanaman nilai-nilai Pancasila. Terdapat substansi kebijakan yang perlu disempurnakan.
\end{abstract}

Kata kunci : Pancasila, karakter, perguruan tinggi, implementasi kebijakan

Social, Humanities, and Education Studies (SHEs): Conference Series p-ISSN 2620-9284 https://jurnal.uns.ac.id/shes e-ISSN 2620-9292 


\section{PENDAHULUAN}

Saat ini bangsa dan negara Indonesia sedang giat-giatnya melaksanakan pembangunan nasional di berbagai bidang. Ini dilakukan dalam rangka perjuangan bangsa mengisi kemerdekaan untuk tercapainya cita-cita nasional, yaitu Indonesia yang merdeka, bersatu, berdaulat, adil dan makmur. Sebagai proses yang multi facet, berkesinambungan dan menuntut partisipasi segenap rakyat, pembangunan nasional ini dihadapkan pada aneka ragam permasalahan, tantangan, hambatan, ancaman dan gangguan. Salah satu aspek penting dalam agenda besar ini adalah manusia Indonesia, baik yang berperan sebagai penyelenggara negara maupun warga bangsa biasa. Dengan kata lain, diperlukan dukungan manusia Indonesia untuk dapat melaksanakan tujuan pembangunan nasional yang telah ditetapkan.

Dalam konteks ini, pembahasan tentang karakter bangsa menjadi strategis, karena akan akan menjadi sesuatu yang kontributif terhadap lancar tidaknya proses pembangunan nasional. Fakta di dalam keseharian kehidupan berbangsa, yang antara lain masih maraknya ujaran kebencian, rasa permusuhan, politisasi agama untuk tujuan politik sesaat, dan intoleransi dari kelompok mayoritas kepada minoritas, merupakan pekerjaan rumah besar yang harus segera mendapatkan penanganan yang tepat. Perilaku sebagian penyelenggara negara yang korup, haus kekuasaan dengan mengalalkan segala macam cara, jual beli jabatan dan pengaruh serta gratifikasi yang tidak kenal malu, merupakan contoh nyata yang seperti sudah mewabah. Patologi birokrasi bukan lagi hanya jadi materi dalam wacana akademis di ruang kuliah, tetapi merupakan fakta sosiologis yang tidak bisa dibantah oleh siapapun.

Kondisi sosial budaya saat ini selaras dengan yang tersebut dalam Lampiran Bab II UU Nomor 17 Tahun 2007 tentang Rencana Pembangunan Jangka Panjang 20052025, bahwa upaya pembentukan karakter bangsa belum optimal, kurangnya keteladanan para pemimpin, lemahnya budaya patuh pada hukum, cepatnya penyerapan budaya global yang negatif, dan kurang mampunya menyerap budaya global yang lebih sesuai dengan karakter bangsa. Berkaitan dengan tantangannya, bahwa derasnya arus globalisasi yang didorong oleh kemajuan teknologi komunikasi dan informasi untuk dapat mempertahankan jati diri bangsa sekaligus memanfaatkannya untuk pengembangan toleransi terhadap keragaman budaya dan peningkatan daya saing melalui penerapan penerapan nilai-nilai Pancasila dan penyerapan nilai-nilai universal.

Dalam konteks ini, pendidikan Pancasila di perguruan tinggi yang bertujuan untuk memberikan pemahaman dan penghayatan kepada mahasiswa tentang ideologi Pancasila merupakan sesuatu yang sangat strategis bagi upaya pembangunan karakter bangsa. Terbitnya UU Nomor 12 Tahun 2012 tentang Pendidikan Tinggi menjadi landasan yuridis yang kokoh bagi upaya itu, karena dalam Pasal 35 disebutkan bahwa matakuliah Pancasila merupakan salah satu mata kuliah dari empat mata kuliah wajib secara nasional atau Mata Kuliah Wajib Umum (MKWU). Dari perspektif kepentingan publik, ketentuan dalam undang-undang itu pada dasarnya merupakan kebijakan publik (public policy), karena selain dirumuskan dan ditetapkan oleh lembaga negara/pemerintah yang memiliki otoritas yang dijamin oleh konstitusi atau peraturan perundang-undangan, juga karena berawal dari adanya masalah publik dan mengandung muatan kepentingan publik. Dilihat dari area substantifnya, maka pengaturan tentang hal ini dapat juga dipandang sebagai kebijakan pendidikan (educational policy).

Penelitian ini bertujuan untuk mengelaborasi hal-hal yang berkenaan dengan pendidikan tinggi, kebijakan publik, kebijakan pendidikan berkaitan dengan MKWU Pendidikan Pancasila, serta peran perguruan tinggi dalam implementasi kebijakan MKWU Pendidikan Pancasila. 


\section{Landasan Teori}

a. Karakter Bangsa

Pembahasan tentang karakter tidak akan terlepas dari pembahasan tentang nilai dan moral dalam kehidupan manusia. Isi dari karakter yang baik menurut Lickona adalah kebaikan. Kebaikan-seperti kejujuran, keberanian, keadilan, dan kasih sayang adalah disposisi untuk berperilaku secara bermoral. Karakter adalah objektivitas yang baik atas kualitas manusia, baik bagi manusia diketahui atau tidak. Kebaikan-kebaikan tersebut ditegaskan oleh masyarakat dan agama di seluruh dunia (2016:15-16). Menurut Lickona character consists of operative values, values in action. Character so conceived has three interrelated parts: moral knowing, moral feeling, and moral behaviour. Good character consists of knowing the good, desiring the good, and doing the good-habits of the mind, habits of the heart, and habits of action (1992:51).

Kebaikan menurut Lickona adalah obyektif yang baik -bukan preferensi subyektif seperti rasa dalam musik atau pakaian- karena kebaikan memenuhi kriteria tertentu: kebaikan menentukan apa artinya menjadi manusia, kebajikan meningkatkan kebahagiaan dan kesejahteraan seorang individu, mereka melayani kepentingan umum, memungkinkan kita untuk hidup dan bekerja di masyarakat (2016:16). Dikemukakan lebih lanjut bahwa terdapat 10 esensi kebajikan yang paling penting untuk membangun karakter kuat, yaitu kebijaksanaan (wisdom), keadilan (justice), keberanian (fortitude), pengendalian diri, cinta, sikap positif, bekerja keras, integritas, syukur, serta kerendahan hati (2016:16-20).

Dengan demikian, sangat jelas arti penting karakter dalam kehidupan bermasyarakat, berbangsa dan bernegara. Lickona mengemukakan lebih lanjut bahwa karakter kehidupan memiliki dua sisi : perilaku benar dalam hubungan dengan orang lain dan perilaku benar dalam kaitannya dengan diri sendiri. Kehidupan yang penuh dengan kebajikan berisi kebajikan berorientasi orang lain, seperti keadilan, kejujuran, rasa syukur, dan cinta; tetapi juga termasuk kebajikan berorientasi diri sendiri, seperti kerendahan hati, ketabahan, kontrol diri, dan berusaha yang terbaik daripada menyerah pada kemalasan.

Berkenaan dengan karakter yang baik, Lickona mengemukakan adanya tiga komponen karakter yang baik, sebagaimana gambar berikut :

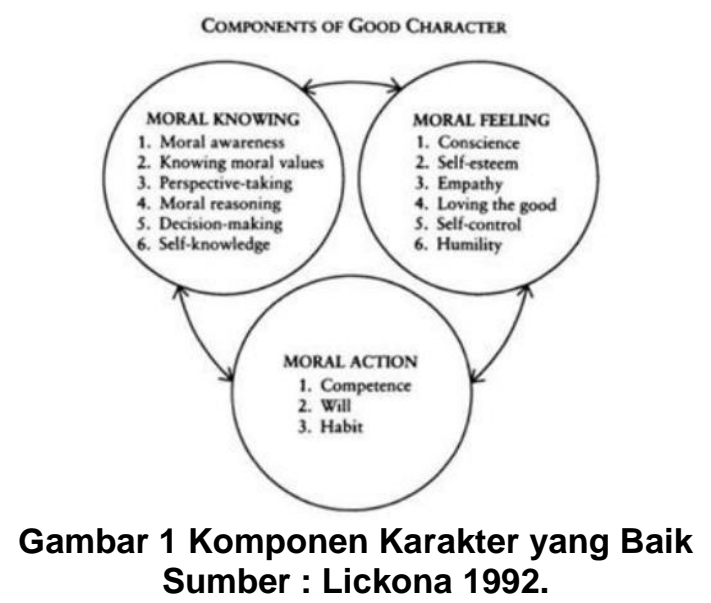

Karakter menurut Ma'arif, merupakan tabiat, akhlak, watak, kepribadian manusia yang lebih condong ke arah positif walaupun pada dasarnya watak, akhlak manusia ada yang buruk atau kurang baik. Karakter tidak hanya melibatkan jasad yang secara fisik terlihat tetapi karakter juga melibatkan psikologis manusia, perasaan serta hati manusia agar karakter tersebut bisa menjadi karakter yang cenderung dan condong ke arah kebaikan. Karakter hanya bisa dibentuk melalui pendidikan yang secara terus menerus (2018:38). 


\section{b. Kebijakan Pendidikan}

Pembahasan tentang kebijakan pendidikan tidak akan terlepas dari kebijakan publik. Kebijakan publik menurut Gerston adalah the combination of basic decisions, commitments, and actions made by those who hold or influence government positions of authority' (2010:7). Post dkk. mengemukakannya sebagai 'a plan of action undertaken by government officials to achieve some broad purpose affecting a substansial segment of a nation's citizens' (1999:172). Salah satu area substantif atau area isu kebijakan publik adalah pendidikan (education), sebagaimana dikemukakan Dunn (1981:47). Dengan kata lain, salah satu jenis kebijakan publik adalah kebijakan pendidikan.

Kebijakan pendidikan secara konseptual dan empirik dapat diletakkan dalam kerangka kebijakan publik maupun administrasi pendidikan dan manajemen pendidikan. Selain itu, kebijakan pendidikan dapat pula diletakkan dalam kerangka kebijakan organisasi atau institusi. Dalam konteks administrasi pendidikan, dikemukakan oleh Sergiovanni dkk bahwa "a policy as any authoritative communication about how individuals in certain position should behave under specified conditions. Organizations control the actions of individuals within them by making and enforcing policy" (1987:17).

Kebijakan pendidikan menurut Carter V. Good merupakan "judgement, derived from some systems of values and some assesment of situational factors, operating within institutionalized education as a general plan for guiding decision regarding means of attaining desired educational objectives" (Imron, 1993:18). Kebijakan pendidikan menurut Imron adalah "salah satu kebijakan negara (public policy). Dengan demikian, kebijakan pendidikan merupakan salah satu sub sistem dari kebijakan negara secara keseluruhan" (1993:19).

\section{METODE}

Metode penelitian yang dilakukan merupakan gabungan dari penelitian kepustakaan (library research) dan yuridis normatif. Fokus peneliti pada berbagai sumber tertulis yang terdapat dalam buku, jurnal dan bentuk dokumen terulis lain yang memuat tentang kebijakan publik, kebijakan pendidikan, pendidikan Pancasila dan karakter, serta pada substansi berbagai peraturan perundang-undangan yang mengatur tentang pendidikan Pancasila dan karakter.

a. Karakter Bangsa

\section{HASIL DAN PEMBAHASAN}

Dari pengalaman sejarah bernegara, kita tidak akan pernah lupa terhadap yang sering Presiden Soekarno katakan sebagai nation and character building. Menurut Anwar S. dan Agus Salim, karakter bangsa adalah salah satu dari sembilan unsur kekuatan nasional tak kasat mata (intangible) suatu bangsa. Sebagai salah satu kekuatan nasional, karakter nasional harus dipelihara dan senantiasa direvitalisasi agar selalu bisa menjadi inspirasi, pengobar semangat dan mampu berfungsi sebagai human capital sebuah bangsa karena karakter nasional menentukan ketahanan nasional bangsa yang bersangkutan (2018:236). Perhatian terhadap pentingnya memberikan perhatian lebih besar pada karakter bangsa, terutama bila kita kaitkan dengan fakta sosiologis saat ini yang penuh dengan ujaran kebencian, hoaks dan narasi permusuhan. Fenomena hoaks, menurut Hidayat, tampaknya semakin akut, dan telah menghinggapi masyarakat kita, bagaikan penyebaran pornografi aatau narkoba. Orang menjadi kecanduan mengonsumsi dan melakukan sesuatu yang dirasa mengasyikkan, namun sejatinya merusak diri dan masyarakat (2019:258). 
Karakter bangsa Indonesia merupakan akumulasi dari karakter tiap manusia Indonesia, yang dalam konteks ideal akan berkenaan dengan nilai-nilai esensial Pancasila, yang sila pertamanya merupakan nilai rohaniah religius yaitu ketuhanan. Nilai menurut Kaelan pada hakikatnya adalah sifat atau kualitas yang melekat pada suatu obyek, bukan obyek itu sendiri. Sesuatu itu mengandung nilai artinya ada sifat atau kualitas yang melekat pada sesuatu itu. Di dalam nilai itu sendiri terkandung citacita, harapan dambaan dan keharusan. Berbicara tentang nilai berarti berbicara tentang das sollen, bukan das sein, kita masuk kerokhanian bidang makna normatif, bukan kognitif, kita masuk ke dalam dunia ideal dan bukan dunia real (2010:80-81). Notonegoro mengklasifikasikan nilai menjadi nilai material, nilai vital, dan nilai kerokhanian. Nilai kerokhanian, terdiri dari nilai kebenaran, nilai keindahan, nilai kebaikan atau moral dan nilai religius. Nilai-nilai Pancasila tergolong nilai-nilai kerokhanian, tetapi nilai kerokhanian yang mengakui adanya nilai material dan vital (Kaelan, 2010:82).

Pembahasan tentang karakter dan pendidikan karakter berkaitan juga dengan konsepsi tentang moral. Moral menurut Suseno selalu mengacu pada baik buruknya manusia sebagai manusia. Bidang moral adalah bidang kehidupan manusia dilihat dari segi kebaikannya sebagai manusia. Norma-norma moral adalah tolok ukur untuk menentukan betul salahnya sikap dan tindakan manusia dilihat dari segi baik buruknya sebagai manusia dan bukan sebagai pelaku peran tertentu dan terbatas (1987:19). Moralitas adalah sifat moral atau keseluruhan asas dan nilai yang berkenaan dengan baik dan buruk. Istilah amoral berarti tidak berhubungan dengan konteks moral atau di luar suasana etis atau nonmoral. Istilah imoral berarti bertentangan dengan moralitas yang baik atau secara moral buruk atau tidak etis. Moralitas menurut Sulismadi dan Sofwani (2011:69) menjadi sumber aturan yang tidak tertulis yang oleh masyarakat dipegang teguh karena ia memiliki nilai-nilai kebaikan sesuai dengan ukuran nilai yang berkembang dalam masyarakat.

Karakter bangsa yang terpancarkan dalam sikap dan perilaku tiap warga bangsanya juga akan berkaitan dengan identitas atau jati dara bangsa. Dalam interaksi manusia di era global saat ini, potensi terjadinya kontaminasi terhadap identitas nasional suatu bangsa akan sangat besar. Berkaitan dengan identitas lain yang menjadi ancaman "identitas" nasional, menurut Bartolomeus Samho, salah satu upaya strategis untuk mengatasinya adalah adanya gerakan sistematik ke arah internalisasi nilai-nilai Pancasila di dalam sektor pendidikan formal tanpa menjadikan Pancasila sebagai instrumen kepentingan politik. Pelaksanaan pendidikan Pancasila hendaknya selalu berorientasi antara lain pada pembangunan karakter generasi bangsa ke arah nilai-nilai seperti ketaatan pada aturan, ketaqwaan kepada Tuhan, kejujuran, keadilan, kedamaian, kebahagiaan, kebebasan, kesederhanaan, penghargaan, kedisiplinan, toleransi, rasa kesatuan, kerjasama, tanggung jawab, cinta tanah air, cinta kasih, dan cinta lingkungan (Bolo dkk.,2012:269).

Karakter bangsa yang diharapkan, tidak terlepas dari program pembangunan nasional sebagai proses perubahan yang multidimensional. Dalam kaitan ini, salah satu misi yang dirumuskan untuk mewujudkan visi pembangunan nasional tahun 20052025 sebagaimana tersebut dalam UU Nomor 17 Tahun 2007 adalah mewujudkan masyarakat berakhlak mulia, bermoral, beretika, berbudaya, dan beradab berdasarkan falsafah Pancasila. Ini diantaranya adalah untuk memperkuat jati diri dan karakter bangsa melalui pendidikan yang bertujuan membentuk manusia yang bertaqwa kepada Tuhan Yang Maha Esa. Sasarannya antara lain terwujudnya karakter bangsa yang tangguh, kompetitif, berakhlak mulia, dan bermoral berdasarkan falsafah Pancasila yang dicirikan dengan watak dan perilaku manusia dan masyarakat Indonesia yang beriman dan bertaqwa kepada Tuhan Yang Maha Esa, berbudi luhur, bertoleran, bergotong royong, berjiwa patriotik, berkembang dinamis dan berorientasi iptek. Arah pembangunan jangka panjang tahun 2005-2025 antara lain bahwa 
pembangunan dan pemantapan jati diri bangsa ditujukan untuk mewujudkan karakter bangsa dan sistem sosial yang berakar, unik, modern dan unggul. Pembangunan jati diri bangsa tersebut dilakukan melalui transformasi, revitalisasi, dan reaktualisasi tata nilai budaya bangsa yang mempunyai potensi unggul dan menerapkan nilai modern yang membangun.

b. Kebijakan MKWU Pancasila

UU Nomor 12 Tahun 2012 yang terdiri dari 100 pasal ini dan ditetapkan pada 10 Agustus 2012, merupakan landasan yuridis yang sangat penting untuk implementasi kebijakan MKWU. Terbitnya ketentuan Pasal 35 ayat (3) UU Nomor 12 Tahun 2012 bahwa Pancasila merupakan salah satu dari empat mata kuliah yang wajib diberikan secara nasional di perguruan tinggi, dari perspektif kebijakan publik sekurangkurangnya berkenaan dengan tiga aspek yaitu aktor kebijakan, institusi kebijakan dan lingkungan kebijakan.

Keberadaan MKWU Pendidikan Pancasila ini sebagai sesuatu yang harus tercantum dalam standar isi Pendidikan Tinggi tidak tercantum dalam Permendikbud Nomor 3 Tahun 2020 tentang Standar Nasional Pendidikan Tinggi. Padahal permen ini merupakan sesuatu yang atributif berdasarkan Pasal 52 Ayat (3) UU Nomor 12 Tahun 2012. Demikian pula hal ini tidak terdapat dalam Permenristekdikti Nomor 44 Tahun 2015 yang dicabut dan dinyatakan tidak berlaku oleh Permendikbud tersebut. Hal yang sama tidak terdapat pula dalam Permendikbud Nomor 49 Tahun 2014 tentang Standar Nasional Pendidikan Tinggi, yang dicabut dan dinyatakan tidak berlaku lagi berdasarkan Permenristekdikti Nomor 44 Tahun 2015.

Undang-undang merupakan produk kebijakan negara yang terbit sebagai bentuk keterlibatan aktor kebijakan, yang ada di institusi negara/pemerintah maupun masyarakat. Dalam tatanan suprastruktur politik, keterlibatan anggota DPR, Presiden, Mendikbud, aparatur birokrasi Kemendikbud, aparatur kementerian lain serta aktor pada lembaga pemerintah lainnya yang langsung maupun tidak langsung dalam perumusan dan penetapan kebijakan tersebut, merupakan wujud nyata pelaksanaan tugas dan fungsinya sesuai peraturan perundang-undangan. Para aktor itu, baik yang elected official maupun appointed official, melaksanakan aktivitasnya sesuai dengan posisi dan status kelembagaannya yang diatur dengan peraturan perundangundangan.

Pada tatanan infrastruktur politik, tampak keterlibatan para aktor kebijakan diantaranya pemerhati pendidikan, media massa, tokoh pendidikan dan pihak lain yang memiliki kepedulian terhadap masa depan anak bangsa. Berbagai kerawanan sosial yang membentang di hadapan mereka tentu merupakan fokus perhatiannya, sehingga turut dalam upaya merumuskan kebijakan pendidikan berupa perlunya matakuliah Pancasila diberikan di perguruan tinggi. Ini penting dikemukakan karena dalam UU Nomor 20 Tahun 2003 tentang Sistem Pendidikan Nasional, matakuliah wajib nasional hanya Pendidikan Kewarganegaraan, Bahasa Indonesia dan Pendidikan Agama. Artinya, selama sembilan tahun pembangunan karakter bangsa tidak didukung secara spesifik oleh matakuliah Pancasila.

Berkenaan dengan lingkungan kebijakan (policy environment), hadirnya kebijakan MKWU Pendidikan Pancasila melalui UU Nomor 12 Tahun 2012, tidak lain karena masih terdapatnya fakta bahwa ancaman ideologis saat ini tidak lebih kecil dari masa sebelumnya. Beberapa persoalan ideologis dalam 20 tahun terakhir mengemuka, diantaranya tentang makin masifnya ide khilafah Islamiah, intoleransi dan radikalisme serta komunisme. Melalui pembelajaran Pancasila, dengan berbagai metode yang bersifat student centered learning, sebagai contoh dosen dapat menunjukkan betapa sangat berbahayanya sikap dan perilaku intoleran dalam kultur masyarakat Indonesia yang plural.

Karakter bangsa yang disemaikan melalui pembelajaran matakuliah ini akan menjadi benteng yang kokoh bagi setiap potensi ancaman yang dapat mengarah pada 
disintegrasi bangsa. Intoleransi, hoaks, fitnah, ujaran kebencian dan rasa permusuhan yang berbalut narasi agama selama ini harus segera diakhiri. Negeri yang indah ini jangan tercabik-cabik hanya karena sikap dan perilaku yang egois demi kepentingan politik kelompok sesaat yang jauh dari semangat kebangsaan. Tragedi kawasan Balkan lebih dari 20 tahun lalu yang meluluhlantakkan Yugoslavia menjadi beberapa negara tidak boleh terjadi di negara yang berfalsafah Pancasila ini.

Kebijakan pendidikan MKWU Pancasila jelas berkaitan dengan pendidikan karakter. Karena itu, untuk terlahirnya manusia dan bangsa yang berkarakter, tentu peran pendidikan karakter sangat strategis dan menentukan. Pendidikan di seluruh dunia menurut Tilaar, kini sedang mengkaji kembali perlunya pendidikan moral atau pendidikan budi pekerti atau pendidikan karakter dibangkitkan kembali. Beberapa sebab, yaitu melemahnya ikatan keluarga, kecenderungan negatif di dalam kehidupan pemuda, serta suatu kebangkitan kembali dari perlunya nilai-nilai etik (2000:74). Pendidikan karakter menurut Hasanah adalah proses usaha yang mengajarkan kebiasaan cara berfikir dan perilaku yang membantu individu untuk hidup dan bekerja bersama sebagai keluarga, masyarakat dan bernegara serta membantu mereka untuk membuat keputusan yang dapat dipertanggungjawabkan (2013:43). Pendidikan karakter menggarap pelbagai aspek dari pendidikan moral, pendidikan kewargaan dan pengembangan karakter. Sifatnya yang multi-faceted membuatnya menjadi konsep yang sulit diberikan di sekolah (Latif, 2018:276).

Dikemukakan lebih lanjut bahwa pendidikan moral menitikberatkan dimensi etis dari individu dan masyarakat serta memeriksa bagaimana standar-standar kebenaran dan kesalahan dikembangkan. Pendidikan kewargaan memberikan kesempatan bagi keterlibatan aktif proses-proses demokratis yang berlangsung di sekolah dan komunitas. Pengembangan karakter adalah suatu pendekatan holistik yang menghubungkan dimensi moral pendidikan dengan ranah sosial dan sipil dari kehidupan siswa. (2018:276-277). Pendidikan karakter, juga dapat dimaknai sebagai pendidikan nilai, pendidikan budi pekerti, pendidikan moral, pendidikan watak yang bertujuan untuk mengembangkan kemampuan individu untuk memberikan keputusan baik-buruk, memelihara apa yang baik, dan mewujudkan kebaikan itu dalam kehidupan sehari-hari dengan sepenuh hati (Muchlas, Samawi, dan Hariyanto, 2013:45-56). Membangun karakter bangsa merupakan proses internalisasi nilai-nilai kehidupan luhur bangsa Indonesia ke dalam jiwa setiap bangsa Indonesia sehingga nilai-nilai tersebut terejawantahkan/termanifestasi dalam perilaku bagi pribadi masing-masing dan bagi kehidupan bermasyarakat, berbangsa, dan bernegara Indonesia (Zabda, 2016:110)

\section{c. Peran Perguruan Tinggi}

Pendidikan tinggi, menurut Pasal 4 UU Nomor 12 Tahun 2012 tentang Pendidikan Tinggi salah satu fungsinya adalah mengembangkan kemampuan dan membentuk watak serta peradaban bangsa yang bermartabat dalam rangka mencerdaskan kehidupan bangsa. Salah satu tujuan pendidikan tinggi sebagaimana tersebut dalam Pasal 5 adalah berkembangnya potensi mahasiswa agar menjadi manusia yang beriman dan bertakwa kepada Tuhan Yang Maha Esa dan berakhlak mulia, sehat, berilmu, cakap, kreatif, mandiri, terampil, kompeten, dan berbudaya untuk kepentingan bangsa. Hal ini berkenaan dengan keberadaan matakuliah Pendidikan Pancasila. Tujuan pokok mempelajari Pancasila di perguruan tinggi menurut Sylvester Kanisius Laku adalah mengajak mahasiswa mempelajari secara kritis Pancasila, baik sebagai wacana moral-yuridis maupun sebagai wacana humanistik, mengajak mahasiswa untuk memahami dimensi pengetahuan dalam Pancasila, serta mengajak mahasiswa untuk merefleksikan secara kritis Pancasila dalam kaitannya dengan kehidupan bersama sebagai bangsa (Bolo dkk, 2012:35-36).

Satuan yang menyelenggarakan pendidikan tinggi adalah perguruan tinggi. Salah satu ciri yang menunjukkan bahwa perguruan tinggi merupakan "partner in 
progress" menurut Tilaar, adalah bahwa output perguruan tinggi haruslah merupakan output yang mempunyai kualitas. Antara lain hasil perguruan tinggi itu melahirkan ilmuwan yang mandiri dan bertanggung jawab. Mandiri dalam berfikir dan inovatif dalam komitmen untuk membangun masyarakat secara keseluruhan (1997:167). Tantangan yang dihadapi perguruan tinggi makin besar seiring dengan permasalahan yang dihadapi bangsa. Dari waktu ke waktu, tantangan dan permasalahan yang dihadapi bangsa dan negara Indonesia, faktanya makin besar dan kompleks, seiring dengan kehidupan manusia yang makin mengglobal. Problem dan permasalahan yang kompleks itu menurut Najmina memerlukan jalan keluar dan tindakan yang nyata. Karakter bangsa yang terpuji, kecerdasan warga yang prima, nasionalisme Indonesia yang kuat, kemampuan hidup dalam masyarakat dan budaya yang multikultural, sangat perlu menjadi fokus pengembangan pribadi setiap warga bangsa (2018:53).

Di sinilah peran perguruan tinggi dipertaruhkan. Perguruan tinggi sesuai dengan otoritas yang dimiliki, sebagaimana disebutkan dalam Pasal 58 UU Nomor 12 Tahun 2012 fungsi dan perannya diantaranya adalah sebagai wadah pembelajaran mahasiswa dan masyarakat serta pusat pengembangan peradaban bangsa. Dengan berbagai sumberdaya organisasi yang dimilikinya, maka pembelajaran MKWU Pendidikan Pancasila sebagimana diatur dalam Pasal 35 ayat (4), tidak saja dilakukan melalui kegiatan kurikuler, tetapi juga kokurikuler dan ekstrakurikuler. Dalam kaitan ini, diperlukan komitmen yang tinggi dari pimpinan perguruan tinggi sebagai aktor kebijakan untuk menempatkan MKWU Pendidikan Pancasila ini secara wajar dan proporsional sebagaimana perlakuan terhadap matakuliah lainnya. Keseriusan terhadap komitmen ini diantaranya akan tampak dalam penugasan dosen yang akan ditugaskan dalam mengampu matakuliah ini, karena akan berkaitan dengan keberlanjutan ideologi nasional.

Berkenaan dengan peran pendidikan, Zaman mengemukakan bahwa modal utama pembangunan adalah pendidikan, karena pendidikan merupakan saarana untuk mencerdaskaan anak bangsa yang nantinya akan menjadi pelaksana pembangunan. Apabila pembangunan dilaksanakan oleh orang-orang yang tidak memiliki karakter kebangsaan, maka pembangunan hanya akan dijadikan sebagai media memperkaya diri dan keluarga semata (2019:27). Dengan pendidikan Pancasila, maka dapat terbangun peradaban bangsa melalui penanaman nilai-nilai moral dan karakter sesuai dengan budaya luhur bangsa. Menurut Herimanto dan Winarno, peradaban berasal dari kata adab yang dapat diartikan sopan, dan budi pekerti, luhur, mulia, berakhlak, yang semuanya menunjuk pada sifat yang tinggi dan mulia (2011:64). Samuel P. Huntington, sebagaimana dikutip Herimanto dan Winarno, peradaban (civilization) sebagai the highest social grouping of people and the broadest level of cultural identity people have short of that which distinguish humans from other species (2011:65). Keberadaban suatu bangsa akan tampak dari karakter warga bangsa yang bersangkutan ketika beraktivitas dengan sesama manusia lainnya.

Pada sisi lain, sebagai ujung tombak implementasi kebijakan, maka dosen pengampu matakuliah sebagai aktor kebijakan juga harus selalu meningkatkan kualitasnya sebagai pendidik. Kesadaran yang tinggi bahwa matakuliah yang diembankan padanya berkaitan dengan keutuhan bangsa dan negara, harus tertanam dengan kuat. Kemauan belajar terus menerus untuk meningkatkan kapabilitas akademik semestinya merupakan bagian dari dinamika kesehariannya sebagai manusia pembelajar. Sebagai aktor kebijakan, mendapat tugas berat tapi mulia karena harus mempersiapkan warga muda bangsa untuk menjadi manusia berkarakter Pancasila. Berkaitan dengan pembangunan karakter ini, perilaku dosen yang ing ngarso sung tulodo juga menjadi bagian penting untuk mengefektifkan tujuan pendidikan Pancasila, karena keteladanan sangat merupakan mutiara kehidupan yang harus tampak dalam setiap relasi kepemimpinan. 
Berkaitan dengan kearifan lokal, dosen dituntut untuk mengelaborasi nilai-nilai lokal yang tumbuh dan berkembang di masyarakat untuk menjelaskan keterkaitannya dengan karakter yang ingin dibangun. Misalnya di daerah Jawa Barat dengan kultur Sundanya, sudah sejak lama dikenal ungkapan "silih asih, silih asah, silih asuh" yang mewarnai gerak kehidupan warga masyarakatnya. Dosen dapat menjelaskan bahwa potensi konflik yang sangat besar terjadi pada masyarakat majemuk seperti Indonesia, akan dapat diminimalkan dengan sikap dan perilaku saling mengasihi meskipun berbeda agama, ras, etnis atau keyakinan politik. Silih asih dalam wujud nyata perilaku keseharian akan berkesesuaian dengan sikap dan perilaku toleran terhadap aneka macam perbedaan.

Mahasiswa punya peran penting dan strategis sebagai role model dalam implementasi kebijakan MKWU Pendidikan Pancasila dalam mendukung pembangunan karakter bangsa. Hal ini karena tidak semua warga bangsa berusia muda memiliki kesempatan menimba ilmu di perguruan tinggi. Dirinya adalah sekelompok kecil rakyat Indonesia yang bernasib baik, karena sebagian terbesar lainnya tidak mendapatkannya. Sebagai calon pemimpin bangsa di masa yang akan datang, terdapat tuntutan pada dirinya untuk dapat tampil sebagai sosok yang memancarkan nilai-nilai Pancasila, terutama ketika sedang berada di tengah masyarakat. Sebagai kekuatan moral, sejarah Indonesia telah mencatat peran besarnya sebagai agen perubahan sosial politik yang membuka episode baru pemerintahan berikutnya. Masa depan Indonesia akan tampak dari tampilan mahasiswa hari jni, karena tidak sampai 20 tahun lagi, sebagian dari mereka akan menjadi pemimpin di berbagai area kehidupan nasional. Mahasiswa hari ini yang berkarakter selaras dengan nilai-nilai Pancasila akan berkontribusi besar terhadap masa depan wajah Indonesia.

\section{SIMPULAN}

Karakter sebagai suatu bangsa sangat diperlukan bagi eksistensi dan kesinambungan perjuangan mencapai cita-cita nasionalnya. Pembangunan karakter dapat dilakukan melalui Pendidikan Pancasila yang telah ditetapkan sebagai bagian dari kebijakan Pendidikan. Perguruan Tinggi memiliki peran strategis dalam mengimplementasikan kebijakan Pendidikan Pancasila untuk mendukung pembangunan karakter bangsa. Terdapat beberapa tantangan dan permasalahan dalam menjalankan fungsi perguruan tinggi dalam mengimplementasikan kebijakan tersebut. Terdapat substansi kebijakan tentang keberadaan mata kuliah Pancasila yang perlu disempurnakan.

\section{DAFTAR PUSTAKA}

Anwar, S. dan Agus Salim. (2018). "Pendidikan Islam Dalam Membangun Karakter Bangsa Di Era Milenial”. Al-Tadzkiyyah : Jurnal Pendidikan Islam. Vol. 9. No.2.

Bolo, A. D. dkk. (2012). Pancasila. Kekuatan Pembebas. Yogyakarta : Penerbit PT Kanisius.

Dunn, William N. (1981). Public Policy Analysis: An Introduction. Prentice Hall Inc. Englewood Cliffts.

Gerston, Larry N. (2010). Public Policy Making. Process and Principles. Third Edition. New York: E Sharpe.

Hasanah, Aan. (2013). Pendidikan Karakter Berspektif Islam. Bandung : Insan Komunika

Herimanto dan Winarno. (2011). IImu Sosial dan Budaya Dasar. Jakarta:Bumi Aksara

Hidayat, K. (2019). Agama Untuk Peradaban. Membumikan Etos Agama Dalam Kehidupan. Jakarta : PT Pustaka Alvabet.

Imron, A. (1993). Kebijaksanaan Pendidikan di Indonesia, Proses, Produk dan Masa Depannya. Jakarta: Bumi Aksara. 
Kaelan. (2010). Pendidikan Pancasila. Yogyakarta : Penerbit Paradigma.

Latif, Yudi. (2018). Wawasan Pancasila. Bintang Penuntun Untuk Pembudayaan. Jakarta : Mizan.

Lickona, Thomas. (1992). Educating for Character : How Our Schools Can Teach Respect and Responsibilty. New York : Bantam Books.

Lickona, Thomas. (2016). Character Matters. Persoalan Karakter. Bagaimana Membantu Anak Mengembangkan Penilaian Yang Baik, Integritas, Dan Kebajikan Penting Lainnya (Juma Abdu Wamaungo dan Jean Antunes Rudolf Zien). Jakarta : PT Bumi Aksara.

Ma'arif, Muhammad Anas, (2018). "Analisis Strategi Pendidikan Karakter Melalui Hukuman Preventif". Jurnal Pendidikan Islam.Ta'allum, Vol.6, No.1, Juni 2018.

Muchlas, Samawi dan Hariyanto. (2013). Konsep dan Model Pendidikan Karakter. Bandung : Remaja Rosda Karya.

Najmina, N. (2018). "Pendidikan Multikultural Dalam Membentuk Karakter Bangsa Indonesia". Jurnal Pendidikan IImu-IImu Sosial. 10 (1) (2018):52-56.

Post, James E dkk. (1999). Business and Society. Corporate Strategy, Public Policy, Ethics. Boston, Irwin McGraw-Hill.

Sergiovanni, T. J. et al. (1987). Educational Governance And Administration. Second Edition. NeW Jersey : Prentice-Hall, Inc. Englewood Cliffs.

Sulismadi dan Ahmad Sofwani. 2011. IImu Sosial dan Budaya Dasar. Malang: UMM Press.

Suseno,Franz Magnis. (1987). Etika Dasar. Masalah-masalah Pokok Filsafat Moral. Jakarta : Kanisius

Tilaar, H.A.R. (1997). Pengembangan Sumberdaya Manusia Dalam Era Globalisasi. Jakarta : PT Gramedia Widiasarana Indonesia.

Tilaar, H.A.R. (2000). Pendidikan, Kebudayaan, Dan Masyarakat Madani Indonesia. Bandung : PT Remaja Rosdakarya.

Zabda, S.S. (2016). "Aktualisasi Nilai-Nilai Pancasila Sebagai Dasar Falsafah Negara dan Implementasinya Dalam Pembangunan Karakter Bangsa". Jurnal Pendidikan IImu Sosial. Vol. 26. No. 2. Desember 2016.

Zaman, B. (2019). "Urgensi Pendidikan Karakter Yang Sesuai Dengan Falsafah Bangsa Indonesia". AL-GHAZALI, Jurnal Kajian Pendidikan Islam dan Studi Islam. Vo.2, No.1, Januari-Juni, 2019.

UU Nomor 17 Tahun 2007 tentang Rencana Pembangunan Jangka Panjang 20052025

UU Nomor 12 Tahun 2012 tentang Pendidikan Tinggi

Permendikbud Nomor 49 Tahun 2014 tentang Standar Nasional Pendidikan Tinggi

Permenristekdikti Nomor 44 Tahun 2015 tentang Standar Nasional Pendidikan Tinggi

Permendikbud Nomor 3 Tahun 2020 tentang Standar Nasional Pendidikan Tinggi 